\title{
A qualitative study on a 30-year trend of tobacco use and tobacco control programmes in Islamic Republic of Iran
}

\author{
Gh. Heydari, ${ }^{7}$ A. Ebn Ahmady, ${ }^{2}$ H.A. Lando, ${ }^{3}$ F. Chamyani, ${ }^{4}$ M. Masjedi, ${ }^{5}$ M.B. Shadmehr ${ }^{6}$ and L. Fadaizadeh ${ }^{7}$
}

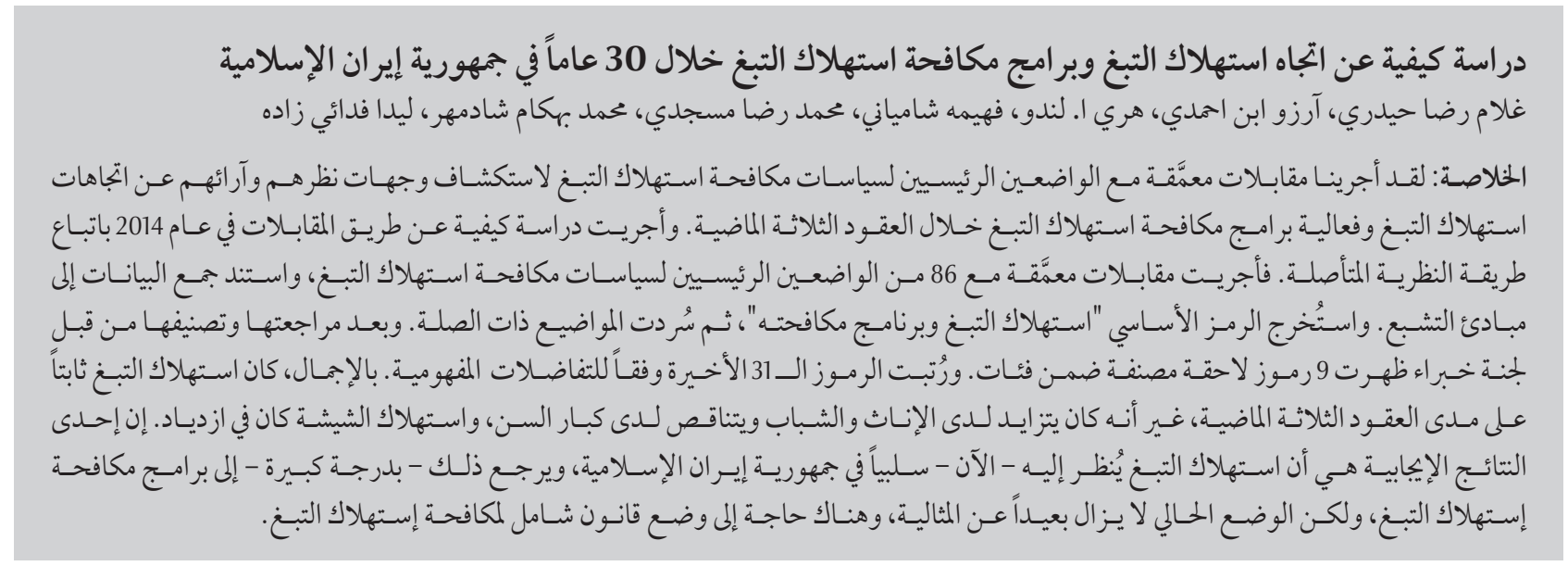

ABSTRACT We conducted in-depth interviews with key tobacco control policy-makers to explore their views and opinions of trends in tobacco use and the effectiveness of tobacco control programmes over the past 3 decades. A qualitative interview study was conducted in 2014 using a grounded theory approach. In-depth interviews were conducted with 86 key tobacco control policy-makers and data collection was based on principles of saturation. The core code "tobacco consumption and its control programme" was extracted and its related themes were listed. After review and classification by an expert panel, 9 categorized codes emerged. The final 31 codes were ordered according to their conceptual differentiations. Overall, tobacco consumption was constant over the past 3 decades; however it was increasing in females and young people and decreasing in older people; hookah consumption was increasing. A positive outcome is that tobacco use is now viewed negatively in the Islamic Republic of Iran, largely due to tobacco control programmes but the current situation is still not ideal and a comprehensive tobacco control law is needed.

Étude qualitative de l'évolution du tabagisme et des programmes de lutte antitabac sur 30 ans en République islamique d'Iran

RÉSUMÉ Nous avons mené des entretiens approfondis auprès de responsables politiques clés de la lutte antitabac afin d'examiner leurs vues et opinions sur les tendances du tabagisme et sur l'efficacité des programmes de lutte antitabac au cours des trois dernières décennies. Une étude qualitative par entretiens a été conduite en 2014 suivant la méthodologie dite de la théorie à base empirique. Des entretiens approfondis ont été menés auprès de 86 responsables politiques clés de la lutte antitabac, et la collecte des données a reposé sur le principe de saturation. Le code source « consommation de tabac et programmes de lutte antitabac » a été extrait et les thèmes apparentés ont ensuite été listés. Après examen et classification par un groupe d'experts, neuf codes catégorisés ont émergé ultérieurement. Les 31 codes finaux ont été ordonnés en fonction de leurs différenciations conceptuelles. Dans l'ensemble, le tabagisme est resté constant au cours des 30 dernières années ; mais il a augmenté chez les femmes et les jeunes, a baissé chez les personnes âgées, et la consommation de houka a connu une augmentation. L'un des résultats positifs est que le tabagisme est à présent perçu négativement en République islamique d'Iran, en grande partie grâce aux programmes de lutte antitabac. Mais la situation actuelle est loin d'être idéale et l'adoption d'une législation antitabac complète est nécessaire.

'Tobacco Prevention and Control Research Centre; National Research Institute of Tuberculosis and Lung Diseases, Shahid Beheshti University of Medical Sciences, Tehran, Islamic Republic of Iran. ${ }^{2}$ Community Oral Health Department, School of Dentistry, Shahid Beheshti University of Medical Sciences, Tehran, Islamic Republic of Iran (Correspondence to Arezoo Ebn Ahmady: a.ebne@yahoo.com; a.ebnahmady@sbmu.ac.ir). (Authors' affiliations continued on page 342)

Received: 16/07/15; accepted: 21/02/16 


\section{Introduction}

Tobacco use is the leading preventable cause of death at the global level $(1,2)$. The WHO Framework Convention on Tobacco Control (FCTC), which was developed in 2003, is an evidencebased set of legally binding provisions that establish a roadmap for successful global tobacco control. 179 countries are parties to the Convention including The Islamic Republic of Iran (3) One of the executive articles of the Convention is to assess the prevalence of smoking in society in order to evaluate the impact of tobacco control programmes on tobacco use (1).

Due to the lack of a comprehensive surveillance system and national survey in past years, the available data are limited to cross-sectional studies (4) or to one or two comprehensive studies (5). The available studies demonstrated different prevalence rates due to differing dates, venues and methodologies of these studies. Based on the available data, tobacco use prevalence declined from $15.3 \%$ (4) to $11.3 \%$ (5) between 2005 and 2007. There also are differing data on smoking prevalence from cross-sectional studies among different groups in Islamic Republic of Iran. For example, prevalence of $20.8 \%$ was reported for military forces in Tehran in 1999 (6); 9.1\% for medical students in 2000 (7); 4\% for secondary school students in Tehran in 2008 (8); 12.1\% for secondary school students in Urmia in 2001 (9); 16.3\% for students in
Tehran universities in 2003 (10); 4.4\% for secondary students in Tehran city in 2004 (11); 7.4\% for medical students of Ardebil University in 2005 (12); $20 \%$ for secondary school students in Gilan in 2007 (13); 24.2\% for medical students in Bandar Abbas in 2008 (14); and about $4 \%$ in global youth tobacco survey in five selected cities in The Islamic Republic of Iran in 2007 (15). When we review the data according to gender and age group the trends and their interpretation become more difficult and unclear. Unfortunately, there is not a comprehensive systematic review and meta-analysis addressing these trends.

According to the WHO MPOWER package report, The Islamic Republic of Iran has scored well in adopting tobacco control programmes (1), and there has been much progress with tobacco control legislation, such as banning smoking on Iran Air short international flights (1992), banning tobacco advertising (1994), banning smoking in public places (1996) and banning smoking on all flights (1997) (16). Heydari et al. (17-19) have demonstrated strong tobacco control programmes in The Islamic Republic of Iran compared to other Eastern Mediterranean Countries. We undertook the current study to explore stakeholders' views of trends in tobacco use and the effectiveness of tobacco control programmes and what key opinion leaders think is the progress on tobacco control during three decades in Islamic Republic of Iran.

\section{Methods}

This paper focuses on using the Grounded Theory method to extract themes regarding tobacco use and the impact of tobacco control over three decades in Islamic Republic of Iran. A qualitative in-depth interview study was conducted following a Grounded Theory approach. An expert panel consisting of Research Committee members of the Tobacco Control Research Centre of Shahid Beheshti University of Medical Sciences gathered the scientific documents and selected the key policymakers (Table 1).

Main core questions and themes (Table 2) were formulated focusing on the trend of tobacco use and tobacco control programmes: strengths, weaknesses, opportunities and threats. Each interview was recorded in audio format.

The study was approved by the Ethics Committee of the National Research Institute of Tuberculosis and Lung Diseases. After obtaining approval, the participants - Health Commission of the Islamic Consultative Assembly of Iran, heads of research centres, Academy of Medical Science, deputies to the Minister of Health and Medical Education and medical universities, senior experts from the tobacco control headquarters office, and members of tobacco control nongovernmental organizations - were informed orally regarding the purpose of the study and signed the written informed consent

\begin{tabular}{lcc}
\hline Table 1 Tobacco control policy-makers who participated in the study & Males & Females \\
\hline Policy-makers & 9 & - \\
Health Commission of the Islamic Consultative Assembly of Iran & 15 & 2 \\
Head of research centres & 14 & 5 \\
University professors in medical sciences & 2 & - \\
Deputies to Minister of Health and Medical Education & 18 & - \\
Deputies to chancellors of medical universities & 4 & 2 \\
Senior experts of tobacco control headquarters office & 10 & 5 \\
Members of tobacco control nongovernmental organizations & 72 & 14 \\
Total & & 5 \\
\hline
\end{tabular}




\begin{tabular}{ll}
\hline Table 2 List of core open-ended questions and themes in the study \\
\begin{tabular}{ll} 
Core questions (first code) \\
1. & What is your opinion about tobacco use in Islamic Republic of Iran? \\
2 & What is your opinion about tobacco control programmes in Islamic Republic of Iran? \\
Themes (second code) \\
1 & Tobacco use in Islamic Republic of Iran \\
2 & Country situation in comparison with the region \\
3 & Country situation in comparison with world \\
4 & History of tobacco control programmes in Islamic Republic of Iran \\
5 & The strength of tobacco control programmes in Islamic Republic of Iran \\
6 & The weakness of tobacco control programmes in Islamic Republic of Iran \\
7 & The threat of tobacco control programmes in Islamic Republic of Iran \\
8 & The opportunity for tobacco control programmes in Islamic Republic of Iran \\
9 & The best strategy for controlling tobacco in Islamic Republic of Iran \\
\hline
\end{tabular}
\end{tabular}

form. All participants were told that they could withdraw from the study at any time they desired. They were assured of confidentiality of tape recordings and transcriptions. The interview was conducted by a trained researcher under supervision of the principal investigator. Data were analysed according to techniques of coding and constant comparison.

Analysis of data began at the first interview. Interviews lasted for 30-70 minutes. Data saturation was achieved after interviews with 86 participants. Data collection began in November 2013 and continued until June 2014. The Corbin and Strauss (20) continuous comparison method was used for data analysis. In this method, data collection and analysis are performed simultaneously. The data analysis process had three phases beginning with an open coding phase. In this phase interview transcripts were read carefully several times, and some statements or sentences were assigned codes in the margins of the transcripts which accurately captured the respondent's meaning. These statements formed the basic concept in Grounded Theory analysis (21). During the axial coding phase, the codes in each interview were then compared with those in each other interview to create broader categories that linked codes across interviews. The aim of categorizing was to reduce the number of codes which were similar or dissimilar into broader higher order categories. The categories were compared with one another. During the comparisons, some of the categories were integrated and sometimes a new class was formed inside the previous ones. This continuous comparison was done carefully until the axial coding was assigned. Finally, selective coding defined the relationship of the classes. During the interviews and data analysis, the researcher wrote down any notes, hypotheses or relationships he found useful in research analysis. The emerging categories were analysed by comparing and contrasting them with each other to ensure that they were exclusive and covered the variations in the data. From this analysis constituting factors emerged, providing elements of a conceptual model. In the last phase further discoveries and clarifying concepts were undertaken, and third level coding with clearer details was extracted.

\section{Results}

86 key tobacco control policy-makers participated in the in-depth interviews (Table 1). In the first phase the two core questions (first codes) regarding tobacco use and tobacco control programmes were determined. The expert panel then reviewed and divided the core codes in a second phase, resulting in nine themes (second codes). Core question 1 was divided to second codes 1,2 and 3 and core question 2 was divided to second codes 4-9 (Table 3). Then in the third phase, the codes were classified into 31 themes (third codes). The codes and their concepts and the evaluation process are shown in Table 3. All 31 third codes were saturated in the study, and nine major themes identified were quoted as below:

- tobacco use is increasing in teenagers and youth

- tobacco use is dramatically increasing among women

- hookah smoking is dramatically increasing in Iiranian society

- the activities of nongovernmental organizations are not enough

- tobacco taxation is insufficient

- presence of quit-smoking services is very important

- having tobacco control law is acceptable

- pictorial health warnings on cigarette packs are not taken seriously

- complete implementation of tobacco-control law is very important. 


\begin{tabular}{|c|c|c|c|}
\hline $\begin{array}{l}\text { Second level codes } \\
\text { (nine codes) }\end{array}$ & $\begin{array}{l}\text { Third level codes } \\
\text { ( } 31 \text { codes) }\end{array}$ & Concepts & Evaluation \\
\hline \multirow[t]{8}{*}{ Tobacco use (1) } & Teenagers and youth (1) & Increasing & Need special consideration \\
\hline & Middle age (2) & Constant & Need to be reduced \\
\hline & Elderly (3) & Decreasing & - \\
\hline & Men (4) & Constant & $\begin{array}{l}\text { Need to be controlled with } \\
\text { medical and educational } \\
\text { interventions }\end{array}$ \\
\hline & Women (5) & Dramatically increasing & $\begin{array}{l}\text { Need to have more specific } \\
\text { strategy }\end{array}$ \\
\hline & Hookah (6) & Dramatically increasing & $\begin{array}{l}\text { Need a coherent and } \\
\text { comprehensive control } \\
\text { programme }\end{array}$ \\
\hline & $\begin{array}{l}\text { Trend of use during three } \\
\text { decades (7) }\end{array}$ & Almost constant & - \\
\hline & Tobacco use's value (8) & Decreased (negative value) & $\begin{array}{l}\text { It is a condemned social } \\
\text { behaviour but more work is } \\
\text { still needed }\end{array}$ \\
\hline \multirow{3}{*}{$\begin{array}{l}\text { Country situation in } \\
\text { comparison with the region } \\
\text { (2) }\end{array}$} & Tobacco use (9) & Decreased & Still far from ideal situation \\
\hline & Tobacco control rules (10) & $\begin{array}{l}\text { Increased (these have } \\
\text { become more stringent) }\end{array}$ & These are sufficient \\
\hline & $\begin{array}{l}\text { Implementation of related } \\
\text { legislation (11) }\end{array}$ & We are behind & $\begin{array}{l}\text { Need for more administrative } \\
\text { supervision }\end{array}$ \\
\hline \multirow{3}{*}{$\begin{array}{l}\text { Country situation in } \\
\text { comparison with world (3) }\end{array}$} & Tobacco use (12) & We are at a medium level & - \\
\hline & Tobacco control rules (13) & We are behind & $\begin{array}{l}\text { Need to use more successful } \\
\text { global patterns }\end{array}$ \\
\hline & $\begin{array}{l}\text { Tobacco control legislation } \\
\text { (14) }\end{array}$ & We are behind & $\begin{array}{l}\text { Need to use more successful } \\
\text { global patterns }\end{array}$ \\
\hline \multirow[t]{3}{*}{$\begin{array}{l}\text { History of tobacco control } \\
\text { programmes (4) }\end{array}$} & $\begin{array}{l}\text { Activities of nongovernmental } \\
\text { organizations (15) }\end{array}$ & Not enough & $\begin{array}{l}\text { Need to have more at country } \\
\text { level }\end{array}$ \\
\hline & $\begin{array}{l}\text { Governmental programmes } \\
\text { (16) }\end{array}$ & Weak & Need to be taken seriously \\
\hline & $\begin{array}{l}\text { Comprehensive tobacco } \\
\text { control law (17) }\end{array}$ & Acceptable & $\begin{array}{l}\text { Highly valued but } \\
\text { need monitoring on its } \\
\text { implementation }\end{array}$ \\
\hline $\begin{array}{l}\text { Strengths of tobacco control } \\
\text { programmes (5) }\end{array}$ & $\begin{array}{l}\text { Presence of comprehensive } \\
\text { tobacco control law (18) }\end{array}$ & Important & $\begin{array}{l}\text { Many countries do not have } \\
\text { this }\end{array}$ \\
\hline \multirow[t]{6}{*}{$\begin{array}{l}\text { Weaknesses of tobacco } \\
\text { control programmes (6) }\end{array}$} & $\begin{array}{l}\text { No enforcement for its } \\
\text { implementation (19) }\end{array}$ & Effective & $\begin{array}{l}\text { Needs enforcement for its } \\
\text { implementation }\end{array}$ \\
\hline & $\begin{array}{l}\text { Laws prohibiting smoking in } \\
\text { public places }(20)\end{array}$ & Numerous violations & $\begin{array}{l}\text { Need monitoring and follow } \\
\text { up }\end{array}$ \\
\hline & $\begin{array}{l}\text { Pictorial health warnings on } \\
\text { cigarette packs (21) }\end{array}$ & Not taken seriously & $\begin{array}{l}\text { Need monitoring and follow- } \\
\text { up }\end{array}$ \\
\hline & $\begin{array}{l}\text { Providing tobacco in } \\
\text { unauthorized units such as } \\
\text { single cigarettes (22) }\end{array}$ & $\begin{array}{l}\text { Regulations have not been } \\
\text { designed carefully }\end{array}$ & $\begin{array}{l}\text { Need for intersectoral } \\
\text { coordination }\end{array}$ \\
\hline & Tobacco tax (23) & Insufficient & $\begin{array}{l}\text { Needs to be increased and } \\
\text { proceeds devoted to tobacco } \\
\text { control programmes }\end{array}$ \\
\hline & $\begin{array}{l}\text { Tobacco cessation services } \\
\text { (24) }\end{array}$ & $\begin{array}{l}\text { The current form does not } \\
\text { work }\end{array}$ & Need to be updated \\
\hline
\end{tabular}




\begin{tabular}{|c|c|c|c|}
\hline $\begin{array}{l}\text { Second level codes } \\
\text { (nine codes) }\end{array}$ & $\begin{array}{l}\text { Third level codes } \\
\text { ( } 31 \text { codes) }\end{array}$ & Concepts & Evaluation \\
\hline \multirow[t]{2}{*}{$\begin{array}{l}\text { Opportunity in tobacco } \\
\text { control programmes (7) }\end{array}$} & Comprehensive law (25) & Important & $\begin{array}{l}\text { Need parliament's supervision } \\
\text { and enforcement for its } \\
\text { implementation }\end{array}$ \\
\hline & Related ministry (26) & $\begin{array}{l}\text { Positive changes in health } \\
\text { sector reform }\end{array}$ & $\begin{array}{l}\text { Need to use available } \\
\text { supports }\end{array}$ \\
\hline \multirow[t]{2}{*}{$\begin{array}{l}\text { Threat in tobacco control } \\
\text { programmes (8) }\end{array}$} & Tobacco industries (27) & Very effective & $\begin{array}{l}\text { Need to work under } \\
\text { supervision of national } \\
\text { tobacco control headquarters }\end{array}$ \\
\hline & Satellite promotion (28) & Effective & $\begin{array}{l}\text { Need to increase public } \\
\text { awareness }\end{array}$ \\
\hline \multirow[t]{3}{*}{$\begin{array}{l}\text { The best strategy for } \\
\text { tobacco control (9) }\end{array}$} & $\begin{array}{l}\text { Implement law completely } \\
\text { (29) }\end{array}$ & Very important & $\begin{array}{l}\text { Need to strengthen main } \\
\text { body of concerned ministries } \\
\text { and tobacco control national } \\
\text { headquarters and implement } \\
\text { annual result-based } \\
\text { programme }\end{array}$ \\
\hline & $\begin{array}{l}\text { Lack of demand in society } \\
\text { (30) }\end{array}$ & Very important & $\begin{array}{l}\text { Need preventive and control } \\
\text { programmes }\end{array}$ \\
\hline & $\begin{array}{l}\text { Presence of quit smoking } \\
\text { services (31) }\end{array}$ & Very important & $\begin{array}{l}\text { Need to have affordable } \\
\text { and accessible medical and } \\
\text { nonmedical interventions }\end{array}$ \\
\hline
\end{tabular}

\section{Discussion}

This study showed that tobacco consumption in The Islamic Republic of Iran has not changed ideally through three decades during which time it was increasing in females and young people and decreasing in older people. This is despite acceptable tobacco control programmes and a number of successes in legislation. The fact that society views tobacco negatively is encouraging but more work is still needed. The current study points to dimensions of tobacco control programmes and their effects on consumption patterns in society.

One of the most important questions in the field of health and tobacco control was "What is the trend of tobacco use in our country over the past three decades?" As there are no data from any surveillance system and annual reports of national surveys on smoking status we have to focus on only a few relevant studies (5). Based on the available information, there were sectional and different answers to this question. In the current study, the experts believe that the trend in the total population is flat but with increasing prevalence in some subgroups including women and young people and decreasing prevalence in other groups such as men and older people. Based on the report of Global Youth Tobacco Survey 2007 results and its comparison to 2003, shows that smoking of other types of tobacco products, especially qalian (water pipe), is the most important problem among young people in The Islamic Republic of Iran in the present and near future. The age when smoking experimentation begins is under 10 years and this makes the issue worse. So, we need to implement a comprehensive action plan for national tobacco control in order to achieve better control on tobacco accessibility for youth and reduce probability of tobacco consumption, especially qalian, among this age group (22). These findings suggest the value of separate tobacco control programmes based on age and gender. The experience of other countries such as China (23) and the USA (24) shows different effects on different subpopulations. Some initiatives have specifically targeted men; others have focused on other groups separately. To achieve substantial decreases in tobacco consumption, significantly increased effort will be needed. In this regard, tobacco control experts agree on the importance of anti-tobacco values in society. All of them believe that during past decades smoking was an intellectual fashion among educated people, whereas there is not such a tendency in society currently. Whereas smoking used to be quite common in public places, at weddings and mourning ceremonies and on public transportation, it is no longer seen or is very uncommon in such settings. But an important weakness in this regard is the use of the hookah. In the experts' opinion, the absence of a comprehensive tobacco control programme that includes hookah smoking and its regular and accurate enforcement and also the focus of tobacco control programmes only on smoking cigarettes in the past two decades has allowed the prevalence of hookah use to increase. This event is not unique to our country; it also has occurred elsewhere in the 
Eastern Mediterranean Region (25) and Mexico (26). These experiences show that we need more accuracy and consistency in order to control tobacco use. This is likely to be true as well in the context of additional emerging products, most notably e-cigarettes.

Another important question in this field is comparison between The Islamic Republic of Iran and other countries on tobacco consumption and tobacco control programmes. This study showed that tobacco consumption in The Islamic Republic of Iran is lower than in other countries of the region and also that tobacco control programmes are more desired. Also, some Eastern European countries and Asian and African countries have reported worse conditions (more smoking less control ) than Islamic Republic of Iran. However, the Islamic Republic of Iran is in the middle and behind many north European countries, Canada, Australia, New Zealand, Thailand and Brazil. These results are consistent with many published studies (16-18,27).

Regarding tobacco control activities, all the experts believed that despite so many efforts undertaken during the past two decades, there is space for more work and increased effort in the country. The presence of one or two popular forums is not sufficient, and establishing new nongovernmental organizations and also alliances and coordination of their activities together will have a greater effect on the government sector and also on society as a whole. This matter was given attention by the members of the Second Conference of the Parties on Framework Convention on Tobacco Control Convention, which focused on effective tobacco control policy (28).

But a particular strength of tobacco control programmes in The Islamic Republic of Iran is compiling a comprehensive tobacco control law. This comprehensive national tobacco control law consisting of 20 articles and five notes was approved by the Iranian parliament in an open session dated 9 July 2006 and contains key articles such as Article 3: any type of direct and indirect tobacco advertising which encourages and stimulates people to smoke cigarettes is strictly banned; Article 4: policy-making, supervision and licences to import various tobacco products shall be arranged by the government only; Article 8: every year, the price of tobacco products shall increase by $10 \%$ through a tax increase - up to $2 \%$ of the total received taxation from tobacco products is transferred to the Treasury Department and shall be allocated to public organizations, charity foundations and nongovernmental organizations; this provides help to these institutions in order to strengthen and promote their educational, research and cultural activities in tobacco control and prevention programmes; Article 9: the Ministry of Health and Medical Education shall coordinate preventive measures, treatment, rehabilitation of tobacco users and cessation counselling services with preliminary health care services. The ministry is also duty-bound to support and improve nongovernmental organizations' activities involved in tobacco cessation counselling and treatment (16).

This is a very useful tool and one that has not been implemented in many countries around the world. This law is based on the WHO Framework Convention of Tobacco Control (1) and nine years after its approval in the Iranian parliament it is a strong basis for many tobacco control programmes in the country. However, parliament has fallen short on enforcement of the law, and some items in particular have been neglected by government and other concerned national authorities. This has been noted as a weakness of the tobacco control programme. What is important in this regard from the experts' point of view is insufficient enforcement for implementation of the tobacco control programme in public places. The law can be very effective and useful based on international documentary evidence. Thus in Ireland (29), stringent tobacco control led to commercial benefits and improved health.

The next important item is to assign appropriate taxes on tobacco products. Unfortunately, currently there is no systematic lobbying effort to increase the retail price up to $75 \%$ (1). For this reason, The Islamic Republic of Iran has lagged behind other countries in the Eastern Mediterranean Region (15). Compensating for this deficiency could be very important step in the implementation of tobacco control programmes. Many studies $(28,30)$ have focused on the positive effects of increased price in reducing tobacco consumption and also increasing governmental income. Furthermore, prior experience indicates that increasing taxes on tobacco will not lead to increased smuggling (31).

Another item pertains putting pictorial health warnings on cigarette packets. Based on the law, effective anti-tobacco pictures should be selected every 6 months to keep the warnings fresh. As in the Hammond (32) and Borland (33) studies, the programme must focus more carefully to reduce demand for tobacco.

Another weakness of tobacco control programmes in our country is the lack of comprehensive tobacco cessation services. Cessation services should be available at no cost. Prior experience in countries such as the USA (34) and England (35) underscored these points.

This study indicates that the presence of a comprehensive tobacco control law and also the existence of tobacco control programmes in the health sector reform plan of the Ministry of Health and Medical Education in the Islamic Republic of Iran provide a unique opportunity to merge and implement tobacco control programmes in government. It is necessary to increase awareness and coordination of concerned health authorities to the importance of tobacco control 
programmes and to providing context for the implementation of countrywide programmes. These points were noted in World Bank recommendations to governments in order to create effective tobacco control programmes and reach higher national and governmental benefits $(36,37)$. However, it also is important to recognize potential threats from the tobacco industry and to focus on and supervise the Iranian Tobacco Company. This can be accomplished through the national headquarters of tobacco control and through coordination with economic and commercial programmes of the Ministry of Industry. This is challenging and requires determination in the national headquarters and prioritization of health in regulating business. Saloji and Dagli (38) in their study mentioned the tobacco industry's efforts to avoid implementation of tobacco control programmes and also focused on governments' awareness of these efforts and not allowing tobacco industry interference in order to achieve tobacco control programmes as called for in the Framework Convention on Tobacco Control (39).

This study demonstrated that the best approach to fight tobacco is to implement a comprehensive tobacco control law through purposeful meetings of the national tobacco control headquarters and related programmes in the main body of the Ministry of Health and Medical Education together with more coordination in government and related organizations. This should include the Ministry of Education. Easy and accessible smoking cessation services should be provided, with the national headquarters of tobacco control taking a more active presence in government, and the president should offer supportive health messages.

\section{Conclusions}

During the past three decades, overall tobacco consumption remained constant, with cigarette smoking decreasing modestly but hookah consumption increasing. The important hopeful points are that tobacco consumption is becoming frowned upon in society and the more favourable condition of Islamic Republic of Iran's tobacco control programmes in comparison with those of neighbouring countries. However, the current situation is far from ideal and complete, and comprehensive tobacco control law is needed including conducting meetings through tobacco control headquarters and having an annual targeted programme with rigorous evaluation.

\section{Acknowledgements}

The authors gratefully acknowledge the experts who have been involved in the tobacco control policy decisionmaking programme in The Islamic Republic of Iran for their participation in this study.

\section{Funding: None.}

Competing interests: None declared.

\section{References}

1. WHO report on the global tobacco epidemic, 2013: Enforcing bans on tobacco advertising, promotion and sponsorship. Geneva: World Health Organization; 2013.

2. Mackay J, Eriksen M. The tobacco atlas. Geneva: World Health Organization; 2012.

3. Jha P, Chaloupka FJ. Tobacco control in developing countries. Oxford: Oxford University Press; 2000.

4. Mehrabi S, Delavari A, Moradi G, Esmailnasab N, Pooladi A, Alikhani $S$ et al. [Cigarette smoking among Iranian population between 15-64 years 2005]. Iran journal of epidemiology. 2006;3(1,2):1-9 [in Persian].

5. Meysamie A, Ghaletaki R, Haghazali M, Asgari F, Rashidi A, Khalilzadeh $\mathrm{O}$, et al. Pattern of tobacco use among the Iranian adult population: results of the national Survey of Risk Factors of Non-Communicable Diseases (SuRFNCD-2007). Tob Control. 2010 Apr;19(2):125-8. PMID:20008159

6. Ramezankhani A, Heydarnia AR, Ghofranipour F, Babali G. [A survey on the prevalence of smoking among Iranian youths entering military service]. Daneshvar Shahed University science research journal. 1999;23(6):53-58 [in Persian].

7. Afrasiabi Far A, Derakhshan A, Sadeghi Hassanabadi A, Rajaei Fard AR. [A survey of cigarette smoking tendency and its associated causes among students of Shiraz University of Medical Sciences, 1998]. Armaghane-danesh Yasuj University medical journal. 2000;20-19(5):42-48 [in Persian].

8. Ziaei P, Hatami-Zadeh N, Vameghi R, Dolatabadi S. [A study on prevalence of cigarette smoking and the age of first smok- ing in senior high school students in Tehran 1998-99]. Hakim research journal. 2008;4(2):78-84 [In Farsi].

9. Shariat Zadeh MR, Sadeghi A. [Epidemiological study of cigarette smoking in Urmia high-school boys]. Tabriz University medical journal. 2001;48(34):27-32 [In Farsi].

10. Masjedi MR, Azaripour H, Heydari G, Alinejad S, Velayati AA. Smoking prevalence among universities students of Tehran. Iran Medical Council journal. 2003;4(20):287-283 [in Persian].

11. Heydari GR, Sharifi Milani H, Hosseini M, Masjedi MR. Attitude of high school students of Tehran towards tobacco use. Tanaffos journal. 2004;3(11):29-35.

12. Majidpour A, Hamidzadeh Arbaby Y, Abbasgolizadeh N, Salehy S .[Prevalence and causes of tendency to cigarette smoking among students in Ardabil University of Medical Sciences]. Ardabil University medical journal. 2005;5(3):266-70 [in Persian].

13. Mohtasham Amiri Z, Cirus Bakht S, Nik Ravesh Rad R. [Cigarette smoking among male high school students in Rasht]. Gilan University medical journal. 2007;65(17):100-7 [in Persian].

14. Aghamolaii T, Zare S. [Pattern of cigarette and water pipe use among people above 15 years in Bandar Abbas]. Hormozgan University medical journal. 2008;11(4):241-6 [in Persian].

15. Jawad M, Lee JT, Millett C. Water pipe tobacco smoking prevalence and correlates in 25 Eastern Mediterranean and eastern European countries: cross-sectional analysis of the Global Youth Tobacco Survey. Nicotine Tob Res. 2016 Apr;18(4):395402. doi: 10.1093/ntr/ntv101. Epub 2015 May 9.. 
16. Campaign for tobacco Free Kids. Tobacco Control Laws. Country Details For Iran (http://www.tobaccocontrollaws.org/legislation/country/iran/laws, accessed 1 May 2016).

17. Heydari G, Ebn Ahmady A, Lando HA, Shadmehr MB, Fadaizadeh L. The second study on WHO MPOWER tobacco control scores in Eastern Mediterranean Countries based on the 2013 report: improvements over two years. Arch Iran Med. 2014 Sep;17(9):621-5. PMID:25204478

18. Heydari G, Talischi F, Algouhmani H, Lando HA, Ahmady AE. WHO MPOWER tobacco control scores in the Eastern Mediterranean countries based on the 2011 report. East Mediterr Health J. 2013 Apr;19(4):314-9. PMID:23882955

19. Heydari G, Talischi F, Masjedi MR, Alguomani H, Joossens L, Ghafari M. Comparison of tobacco control policies in the Eastern Mediterranean countries based on Tobacco Contro Scale scores. East Mediterr Health J. 2012 Aug;18(8):803-10. PMID:23057368

20. Strauss AL, Corbin JM. Basics of qualitative research. London: Sage Publications; 1990.

21. Priest H, Roberts P, Woods L. An overview of three different approaches to the interpretation of qualitative data. Part 1: Theoretical issues. Nurse Res. 2002;10(1):30-42. PMID:12405004

22. I.R. Iran Global Youth Tobacco Survey (GYTS) Report 2007 (http://www.who.int/tobacco/surveillance/Iran\%20 GYTS2007\%20final\%20report2.pdf?ua=1, acessed 1 May 2016)

23. Liu Y, Rao K, Hu TW, Sun Q, Mao Z. Cigarette smoking and poverty in China. Soc Sci Med. 2006 Dec;63(11):2784-90. PMID:16959391

24. Everett SA, Warren CW, Sharp D, Kann L, Husten CG, Crossett LS. Initiation of cigarette smoking and subsequent smoking behavior among U.S. high school students. Prev Med. 1999 Nov;29(5):327-33. PMID:10564623

25. Nassar $\mathrm{H}$. The economics of tobacco in Egypt, a new analysis of demand. Washington DC: World Bank; 2003. [: (http:// repositories.cdlib.org/context/tc/article/1120/type/pdf/ viewcontent/, 1 May 2016)

26. Sesma-Vázquez S, Campuzano-Rincón JC, Carreón-Rodríguez VG, Knaul F, López-Antuñano FJ, Hernández-Avila M El comportamiento de la demanda de tabaco en México: 1992-1998 [Trends of tobacco demand in México: 19921998]. Salud Publica Mex. 2002;44 Suppl 1:S82-92. [Spanish] PMID:12055750

27. World Health Organization. World health report 2002. Geneva: World Health Organization; 2002 (http://www.who.int/ whr/2002/Overview_E.pdf, 1 May 2016).

28. World Health Organization. Conference of the Parties to the WHO Framework Convention on Tobacco Control. First report of Committee A (Draft) (A/FCTC/COP/2/17) 4 July 2007 (http://www.who.int/gb/fctc/PDF/cop2/FCTC_COP2_17Pen.pdf, 1 May 2016)

29. Fong GT, et al. Reductions in tobacco smoke pollution and increases in support for smoke-free public places following the implementation of comprehensive smoke-free workplace legislation in the Republic of Ireland: findings from the International Tobacco Control (ITC) Ireland/UK Survey. Tob Control. 2006;15 Suppl. 3:iii51-8. PMID:16754947

30. Van Walbeek C. Tobacco excise taxation in South Africa: tools for advancing tobacco control in the XXIst century: success stories and lessons learned. Geneva: World Health Organization; 2003. (http://www.who.int/tobacco/training/success_stories/en/best_practices_south_africa_taxation.pdf, accessed 13 May 2016)

31. Joossens L. Report on smuggling control in Spain. Geneva: World Health Organization; 2003. [cited 6 December 2007]. Available from: (http://www.who.int/tobacco/training/success_stories/en/best_practices_spain_smuggling_control. pdf, accessed 13 May 2016)

32. Hammond D, Fong GT, McNeill A, Borland R, Cummings KM Effectiveness of cigarette warning labels in informing smokers about the risks of smoking: findings from the International Tobacco Control (ITC) Four Country Survey. Tob Control. 2006 Jun;15 Suppl 3:iii19-25. PMID:16754942

33. Borland R. Tobacco health warnings and smoking-related cognitions and behaviours. Addiction. 1997 Nov;92(11):1427-35. PMID:9519486

34. Solberg LI, Maciosek MV, Edwards NM, Khanchandani HS Goodman MJ. Repeated tobacco-use screening and intervention in clinical practice: health impact and cost effectiveness. Am J Prev Med. 2006 Jul;31(1):62-71. PMID:16777544

35. Fiore MC. Treating tobacco use and dependence: a public health service clinical practice guideline. Rockville, Maryland: US Department of Health and Human Services, press briefing, 27 June 2000 (http://www.ncbi.nlm.nih.gov/books/ NBK63952/, accessed 1 May 2016).

36. Jha P, Chaloupka FJ. Curbing the epidemic: governments and the economics of tobacco control. Washington DC: World Bank; 1999. (http://documents.worldbank.org/curated/ en/1999/05/437174/curbing-epidemic-governments-economics-tobacco-control, accessed 8 June 2016).

37. Tobacco control at a glance. Why is reducing use of tobacco a priority? Washington DC: World Bank; 2003 (http://siteresources.worldbank.org/ INTPHAAG/Resources/AAGTobacControlEngv46-03.pdf, accessed 1 May 2016).

38. Saloojee Y, Dagli E. Tobacco industry tactics for resisting public policy on health. Bull World Health Organ. 2000;78(7):90210. PMID:10994263

39. Conference of the Parties to the WHO Framework Convention on Tobacco Control (FCTC), Bangkok, guidelines adopted July 2007. Geneva: World Health Organization, WHO Framework Convention on Tobacco Control-Second Session of Conference of the Parties (http://www.who.int/fctc/cop/sessions/ second_session_cop/en/, accessed 1 May 2016).

Authors' affiliations continued from page 335

${ }^{3}$ Division of Epidemiology and Community Health, School of Public Health, University of Minnesota, Minneapolis, United States of America ${ }^{4}$ Department of Library, National Research Institute of Tuberculosis and Lung Diseases, Shahid Beheshti University of Medical Sciences, Tehran, Islamic Republic of Iran. ${ }^{5}$ Chronic Respiratory Research Centre, National Research Institute of Tuberculosis and Lung Diseases, Shahid Beheshti University of Medical Sciences, Tehran, Islamic Republic of Iran. ${ }^{6}$ Tracheal Diseases Research Centre, National Research Institute of Tuberculosis and Lung Diseases, Shahid Beheshti University of Medical Sciences, Tehran, Islamic Republic of Iran. ${ }^{7}$ Telemedicine Research Centre, National Research Institute of Tuberculosis and Lung Diseases, Shahid Beheshti University of Medical Sciences, Tehran, Islamic Republic of Iran. 